\title{
Social and investment redistribution - the trend of the future
}

\author{
Elizaveta Donchenko ${ }^{1 *}$ and Sergey Shaginyan ${ }^{1}$ \\ ${ }^{1}$ Rostov State Transport University, Rostovskogo Strelkovogo Polka Narodnogo Opolcheniya Sq., 2, \\ Rostov-on-Don, 344038, Russia
}

\begin{abstract}
Russia is going through a stage of becoming accompanied by complex internal problems. They are associated with the development of a legal framework and reconsidering the new type of economy, the negative impact of global crises and evident challenges in the distribution of the money supply. An active social policy of the state is aimed at the population strata in need of support: pensioners, disabled people, children. But the gap between low-income and rich groups is widening, and the middle stratum as a social component has practically disappeared. This situation suggests the need to search for tools to improve the prosperity of the population. Besides, low-efficiency investment systems of large players in the sector with state participation are registered, which requires the search for additional sources of investment and ways of their rational use with proper control. Which, in its turn, will reset the load from the state budget.
\end{abstract}

\section{Introduction}

Many countries all over the world are addressing the issue of social equality, especially those that have experienced rapid economic growth.

And it was this fact that demonstrated the growing gap between the rich and the poor, between actively-developing types of business and uncertainty of infrastructure. The importance of considering these issues is addressed in the studies of Chinese economists, who indicate that "without the support of effective social policy, economic growth cannot be sustainable" [1].

The search for opportunities to stabilize social phenomena drew our attention to the model developed by John M. Keynes, which combines several significant parameters of society affecting growth of the population's prosperity.

The scientist deduced several laws which are also effective in times of crisis. He determined the role of the state and the degree of responsibility. Keynesian work showed the possibility of combining microeconomic indicators into a single macro-system. And even though the theory in question has many opponents, there are also followers. They do not only support the derived postulates but also actively develop them. According to $\mathrm{M}$.

* Corresponding author: liza161@,bk.ru 
Milgate, the work of J. M. Keynes "is a valuable reference for economists and researchers interested in the interrelation of capital and employment" [2].

Modern scientists are also making attempts of model-building in search of evidence of the effectiveness and rationality of the proposed innovations.

Alberto Bucci and Alberto Russo [3] speak about the influence of finance on long-term development with the proper organization of its direction and its orders. Tobias Götze and Marc Gürtler discuss the role of securities in the insurance system [4].

Our research is aimed at finding ways and means to raise prosperity, primarily of the employable population having low incomes and personnel of large industrial companies with state participation.

The choice of the corporation was obvious. The transport industry is one of the most problematic, but at the same time it is highly-demanded for our living. Russian Railways is one of the largest companies experiencing some difficulties with the investment system. The study has revealed significant gaps the elimination of which may have a positive effect on the growth of income of the company's employees and its capitalization.

Micro-economic opportunities are not involved, the implementation of which is constrained by the institutional-recessionary economy, management conservatism and inconsistency of economic interests.

We believe that in this case a mechanism for the redistribution of the corporate level uniting the interests of the corporation and the personnel is prospective. The proposed mechanism is based on the model of J.M. Keynes, transforming the concept of the macrolevel to the micro-level of Russian Railways (JSCo RZD).

\section{Materials and methods}

Adhering to the generally accepted rules of scientific and practical research, we used empirical methods - observation, comparison, classification.

Theoretical methods included formal logic, and specifically modelling. Also, we employed statistical analysis, exploration of developments and approaches to solving the stated problem by domestic and foreign schools and practical solutions based on the experience of foreign and domestic companies.

\section{Results}

Nowadays, investments as an economic category cannot be considered only from a theoretical point of view.

The need and prospects for transforming the macro- and microeconomic environment dictate a rational approach and actualize the development of investment policy, its mechanism and tools and its implementation within specific industries and companies.

In the course of our study we identified several main reasons for the low efficiency of investment activity of JSC "Russian Railways". Among these we include:

- on the part of the state - the negative impact of state policy (state monopoly, problems of economic literacy), legislative barriers (limited sources, lack of benefits, lack of compensation for losses and negative earnings), lack of mutual responsibility;

- within the company - lack of targeted focus of investment projects, limited tools for the investment process, imperfect forms and methods of engaging investment resources, lack of awareness and public control.

This division is relative because all the reasons are interrelated and co-dependent, their combination aggravates the situation, which is expressed, primarily, in a shortage of investment resources. 
With relatively large-scale investments into Russian Railways, there is a clear deficit of them, which hinders the necessary progressive development of the transport holding, including the innovative one [5].

The main sources (inhouse and government) are limited by profit, the possibilities of state financing and the directions of their use (a significant share provides simple reproduction, and has the nature of subsidies). It is necessary to search for an additional source, innovative for the domestic economy, a mechanism and tools for corporate investment, mediated by redistribution processes that combine economic interests of the subjects of accumulation, transformation, investment use and distribution of the increased value.

The classical and Keynesian SI savings-investment models solve problems and provide macroeconomic equilibrium.

At the same time, the methodology and tools for its implementation can be used at the level of a macro-forming company, which is Russian Railways. In our opinion, the transfer of the macro-level economic philosophy to the micro-level will allow not only to universalize the mechanism of social and investment redistribution but also to enrich it with processes that take into account the specific nature of the leading transport company.

In the redistributive process we are considering social savings are the basic component of the investment and savings process, which is most fully considered and substantiated by J.M. Keynes.

As a part of income, savings surpassing consumption are an integral part of an active investment process.

The saved part of the income is not only associated with the investment activity of the population but also through individual instruments has a significant impact on the volume of production and the level of unemployment.

The accumulation process depends not only on the level of income but also on the motives of behaviour dictated by the ability to foresee the economic situation in the future.

The motives and factors affecting the choice in favour of savings were studied by Adrian Furnham and Helen Cheng [6].

Redistribution is a set of numerous tools for the interaction of all actors in the distribution process: owners and users of production factors connected by economic and social interests.

The more complex economic relations are and the more developed the economic system is, the more widespread and effective are the mechanisms and instruments of redistribution. In our case, these are the tools for transforming social savings into investments and, as a sign of their effectiveness, the growth of welfare and capitalization.

Transforming the economics philosophy of redistribution of macrolevel into microlevel is a logical continuation of the development of social and investment redistribution.

State participation as a stimulator of investment activity and a regulator of social savings has not been realized yet.

We should note that potential investors are not sufficiently informed and aware of their opportunities to gain additional income and other benefits from the manifestation of investment activity.

Similar problems occur in our country and in some other countries likewise. It is confirmed in the study "Individual Investor Ownership and the News Coverage Premium" by Paul Marmora [7].

A low level of general economic and financial literacy entails adverse outcomes for all subjects of investment and redistribution relations, limiting investment activities, restraining the development of the economy, hindering the growth of effective instruments:

- consumers of financial services: citizens and corporations;

- institutions providing financial services; 
- the state regulating the financial market.

Attempts are made to implement educational programs through further training as part of the extension of competencies for students of high schools.

As for adults, citizens of pre-retirement age have been involved after the pension reform was launched. The information environment focuses on familiarization with the legal framework - complex and obscure [8].

There are positive aspects of this process, in our opinion, which is the emergence of involving and motivating training programs which have been developed and implemented by the interested banking structures in the recent two years, such as Sberbank, VTB, Tinkoff and insurance parties included in their group.

Involving corporate workers and population into economic development must provide overcoming low level of financial literacy and understanding the processes of redistribution and its socio-economic, institutional and informational characteristics and also methodological approaches.

Insufficient activity coupled with a lack of basic knowledge of the financial market, a lack of desire to take responsibility, supported by the low standard of living of the population, are aggravated by an inconsistent reform system on the part of the state, a lack of effective means of consumer protection; weak regulation of the insurance market, including the pension market, and a paucity of motivational and stimulating instruments.

All this contributes to citizens' distrust in the existing financial institutions and government agencies. As a result, the population is actually excluded from the number of economic entities - potential investors.

The results of diagnosing the investment problems of the Russian transport company have outlined some areas of study of the practising schemes and tools of social, structural, organizational-managerial and banking-financial properties.

Attention has been drawn to the corporate social responsibility (CSR), which originated in the $50 \mathrm{~s}-70 \mathrm{~s}$ of the previous century and affects different issues, including social security of personnel and sponsorship of social protection.

The CSR implementation program has become widespread, its level being the designation of the company's status in the world ranking. CSR includes several items. Its influence on different risks and optimality of investment is studied on the example of corporations in the Asia-Pacific region [9].

The study of foreign experience and the emerging domestic practice of engaging temporarily free funds from the population through the institutions of social and investment redistribution makes it possible to systematize its instrumental elements into accumulation and transformation subsystems and to substantiate the relevance of the development of the mechanism within the company.

Studies in the field of engaging part of the population's income into the economic development of different countries have shown that substantial results were achieved due to the reservoir-investment role of savings, the share of which in personal income, for example, in Japan equals 20\%, in Germany, France, Italy equals $11-12 \%$.

In the redistribution process, personal savings account for $1 / 3$ of all capital investments.

As a reverse effect, there is a decline in production in the post-crisis period: studies note that a decrease by $1 \%$ in production is associated with a decrease in investment by $2.4 \%$.

Trends in the development of investment business and the totality of existing financial and non-financial instruments, management of investment processes are revealed.

In the American practice, where the state stimulates a high level of consumption, and, consequently, the share of savings is relatively low, the investment business is mobile, multi-structure, and the stock market is primary in active attracting of savings. 
In the EU countries, particularly in Germany, an active conductor of savings in investments is the banking and financial sector, through which savings are channelled to investment-attractive sectors of the economy.

At the same time, all national models demonstrate rationality, regulatory security and, on the part of the state, an ability to control and support accumulation institutions and the direction of transforming the unused part of the population's income into the future development of the economy. In the Asian practice, where the share of savings is much higher, there is a clear pattern of government regulation and planning.

These conclusions will help to find options of efficient solutions when choosing incentives, motives and tools, and an effective working mechanism of social and investment redistribution on the scale of a large corporation.

As a result of studying the international experience of using promising and effective instruments, we have outlined the Block of Savings and Investment Income, the Block of Savings Accumulation, and the Block of Savings Transformation.

The Block of Savings and Investment Income is designated as the determining one. It contains the key corporate components: the company itself, which is in need of constant and massive investments; a source of constant investment - savings of employees (population); the possibility of forming corporate structures (pension fund, insurance company, investment fund, corporate bank) - under the general management and organization of savings and investment processes.

The instruments included in this block are extremely clear and profitable: interest rate on the deposit; investment dividends; the opportunity to choose an income-generating pension plan, lucrative insurance services and special conditions of the banking sector, including favourable lending; an expanded range of stimulating social services (nonmaterial).

The widest group of institutions is represented by the Block of Savings Accumulation this is a common international practice that indicates the interest of the state and business in attracting private investment to decrease the burden [10].

The degree of development, efficiency, structural features depend on national approaches and legislative frameworks.

Affiliation is exclusive and characterized by elements of corporate and/or industryspecific form. The accumulation institutions include the securities market, investment banks, universal banks, development banks, stock and guarantee banks, public pension funds, private pension funds, corporate pension funds, savings banks such as pension, insurance, construction ones; insurance entities, insurance companies. The direction and affiliation of institutions determine the set of tools and the direction for the development. The tools for substantiating the possibility of accumulating savings for investment purposes are the state target strategy, state incentives, state support, state control, regulatory support, tax preferences, information consulting. State participation directly depends on investment policy and legislation, but progressive systems are mobile and promptly respond to challenges and threats. The tools described above are the macro level, the basic component of the corporate micro-level efficiency. A modern feature of this stage is state support for national economic systems of a new format and the urgent need for their formation [11].

The Block of Savings Transformation into investments is limited to the stock market, investment companies, investment banks which run investment business.

The same institutions can carry out direct investments, providing that they are merged with the pension, insurance institutions, insurance funds, etc. The instruments include securities, investment lending, direct investment, risk redistribution, corrective linking mechanisms, mobile changes in legislative conditions. We should draw attention to the absence of management companies, which does not mean their absence in the savings and investment structures. They develop under certain conditions, and those functions which 
contribute to the development of investor relations are legally defined, in contrast to the functions of Russian management companies, whose activities will be discussed in the next paragraph. The international experience of the institutions of this block is of interest because the states are guided by the trends and forecasts of the investment business, which are expressed in loyal legislative reforms.

Foreign experience and the emerging domestic practice of engaging temporarily free funds from the population through the institutions of social and investment redistribution made it possible to systematize its instrumental elements into subsystems and substantiate the relevance of the development of the mechanism within the company.

So the authors (Reshetnikova et al. (2019)), to have a high degree of enterprise financial security is considered «to be able to develop and implement the financial strategy independently following the objectives of the overall corporate strategy and the principles of corporate governance in conditions of uncertain" [12].

The domestic practice of corporate redistribution of a social and investment nature is represented primarily by corporate plans for non-state pension insurance, some relatively voluntary insurance, certain areas of mutual investment funds that bring them closer to the low-income stratum of the population, banking programs for loyal and VIP clients, instrumental elements of corporate social responsibility.

Exploring the possibility of involving low-income strata of the population into investment process is not new and has been studied by some foreign authors [13].

The corporate mechanism of social and investment redistribution of Russian Railways is algorithm-driven by the purpose; tasks; organizational and functional principles all of which unite the logistics of the functions of intercorporate institutions by means of its instruments (directors, accumulators, transformers, recipients, guarantors) and formalizing the methodological model of "income-savings-investment-income" [14].

A subsystem toolkit has been determined that corresponds to the elements of the system of corporate institutions (corporate pension fund, insurance company, investment fund, universal bank, management company), the strategic partnership of which is based on the interdependent control of collective investments [15], distribution of investment profits and guarantors of the mechanism (state, corporation, society), ensured by the improvement of the relevant law principles on the macro-and micro-level, and providing universality of the system of corporate social and investment redistribution [16]. figure 1 .

The element of the corporate mechanism of social and investment redistribution in the



Fig. 1. The element of the corporate mechanism of social and investment redistribution for the accumulation and transformation of savings, compiled by the author.

Thus, the SI macroeconomic model adapted to the corporate conditions of Russian Railways, in our opinion, is fully justified and looks promising in solving the main task convergence of the economic interests of its subjects (growth in prosperity of the personnel and capitalization of the holding). 


\section{References}

1. K. Guo, J. Hang, S. Yan, China Economic Review, 101621 (2021)

2. M. Milgate, Capital and employment: a study of Keynes's economics (Academic Press, 2014)

3. A. Bucci, A. Russo, Finance and long-term growth: Economic modelling and evidence, 188-192 (2019)

4. T. Götze, M. Gürtler, Journal of Economic Behavior \& Organization (2019)

5. S.G. Shaginyan, E.G. Dohchenko, Science and Education: Farming and Economy; Entrepreneurship; Law and Governance 11, 30-33 (2016)

6. A. Furnham, H. Cheng, Journal of psychiatric research 113, 46-50 (2019)

7. P. Marmora, The Quarterly Review of Economics and Finance (2021)

8. E.G. Donchenko, Competitiveness in the Global World: Economics, Science, Technology 9, 1 (2016)

9. S. Utz, Review of Financial Economics, Review of Financial Economics, 36(2), 167193 (2018), https://doi.org/10.1016/j.rfe.2017.10.001

10. V. L. Okulov, K. R. Khafizova, Vestnik of Saint Petersburg University. Management 17, 2 (2018)

11. E.G. Donchenko, Izvestiya Vuzov. Severo-Kavkazskii Region. Social Sciences 1, (2018)

12. N. Reshetnikova, M. Magomedov, D. Buklanov, E. Zakharchenko, Lecture Notes in Networks and Systems, 57 (2019) https://doi.org/10.1007/978-3-030-00102-5 31

13. E.G. Donchenko, News of Higher Educational Institutions. A Series Economy, Finance and Production Management 1 (43) (2020)

14. L. Becchetti, L. Bruni, S. Zamagni, The Microeconomics of Wellbeing and Sustainability: Recasting the Economic Process (Academic Press, 2019)

15. A.K. Sen, The idea of justice (Harvard University Press, 2009)

16. E.G. Donchenko, Formation of Social Redistribution and Investment System of the Transport Company: monograph (Rostov State Transport University, Rostov-on-Don, 2016) 